\title{
Parental Attitude Perceived by University Students as Predictors of Subjective Well-Being and Life Satisfaction
}

\author{
Mehmet Engin Deniz ${ }^{1}$, Özlem Karakuş², Zeliha Traş ${ }^{3}$, Jale Eldeleklioğlu \\ Zümra Özyeşi1 ${ }^{4}$, Erdal Hamarta ${ }^{3}$ \\ ${ }^{1}$ Department of Guidance and Counselling, Faculty of Education, Yildiz Technical University, \\ Istanbul, Turkey \\ ${ }^{2}$ Department of Social Work, Faculty of Health Science, Selcuk University, Konya, Turkey \\ ${ }^{3}$ Department of Guidance and Counselling, Faculty of Education, Necmettin Erbakan University, \\ Konya, Turkey \\ ${ }^{4}$ Department of Psychology, Faculty of Arts and Sciences, Istanbul Arel University, Istanbul, Turkey \\ Email: edeniz@yildiz.edu.tr, ozikarakus@gmail.com,zs_selcuk@yahoo.com,zumraozyesil@arel.edu.tr, \\ ehamarta@selcuk.edu.tr
}

Received December $24^{\text {th }}, 2012$; revised January $23^{\text {rd }}, 2013$; accepted February $25^{\text {th }}, 2013$

\begin{abstract}
The study aims to analyze whether parental attitudes (democratic, protective, and authoritarian) predict subjective well-being and life satisfaction of university students. Subjects in the study were 414 students, 221 female and 193 male. Perceived Parental Attitudes Scale, Subjective Well-Being Scale and Life Satisfaction Scale were used as data collection tools. Pearson product moment correlation coefficient and multiple regression analysis were used in the analysis of data. Positive significant relationship was found between democratic parental attitude and subjective well-being and life satisfaction scores; negative relation was found between protective and authoritarian parental attitude and subjective well-being and life satisfaction scores $(p<.001)$. According to regression analysis, perceived parental attitudes predict subjective well-being and life satisfaction significantly
\end{abstract}

Keywords: Parental Attitude; Subjective Well-Being; Life Satisfaction

\section{Introduction}

Subjective well-being is defined as individuals' regarding their lives as being valuable (Diener, 2000). Subjective well being is a term related to a person's being aware of his potential, purpose of life and also psychological well-being which determines interpersonal relationships (Ryff \& Keyes, 1995). There are three points which determine the level of subjective wellbeing: general life satisfaction, multitude of positive feelings and scarcity of negative feelings (Myers \& Diener, 1995).

Subjective well-being is the overall evaluation about how individuals regard their life in various aspects. People can make an evaluation based on a general judgment such as the course of their life, life satisfaction and sense of achievement; it includes a general evaluation of an individual upon living spaces such as school, marriage or business or their current feelings (Diener, 2000, 1984). According to this, if individuals are satisfied with their living space and they experience more positive and less negative feelings, it can be said that they have a high level of subjective well-being, since it depends on the measurement of positive feelings.

Subjective well-being consisting of three components: life satisfaction, the presence of positive mood and the absence of negative mood together often summarized as happiness (Ryan \& Deci, 2001). Life satisfaction reflects the sum of an individual's positive feelings about the quality of his life and cognitive judgment about this satisfaction (Dost, 2004). Subjective well-being and happiness are equivalent with the term life satisfaction (Veenhoven, 1996; Diener, 2000; Diener, Suh, \& Lucas, 2003). In the literature, life satisfaction was defined as the attitude towards life determined as time for work, spare time and off-hours (Diener, 2000), compensation of basic needs and other attainable needs at a certain extent (Bradley \& Corwyn, 2004), being well in the sense of happiness and spirits (Vara, 1999) and positive feelings being dominant over negative feeling in daily tasks (Aksaray, Yıldız, \& Ergün, 1998).

Studies show that there is a positive significant relation between subjective well-being and life satisfaction (Petito \& Cumins, 2000; Suldo \& Huebner, 2004; Dew \& Hubner, 1994). On the other hand, variables which indicate and increase general life quality such as emotional intelligence, humor (Tümkaya, Hamarta, Deniz, Çelik, \& Aybek, 2008), self-respect (Hamarta, 2009; Huebner, Gilman, \& Laughlin, 1999), happiness (Furnham \& Cheng, 2000), subjective well-being (Tuzgöl-Dost, 2010), problem solving (Hamarta, 2009), and coping with stress (Deniz, 2006) were also studied. Moreover different sampling groups such as problematic teenagers (Köker, 1991), university students (Deniz \& Y1lmaz, 2004) and university academicians (Tümkaya at el., 2008) were considered.

Family which is one of the individual, objective and social elements (Toros, 2001) determine the quality of life satisfaction and is placed on the basis of individual and society relation. Parent factor which forms the family has also an important role in determination of children's life (Baumrind, 1980). Studies on child-rearing attitudes of developmental psychology is based on very old dates. Parental attitude was also mentioned in Psychodynamic and Behavioral Model, Baumrind's Classification, and Maccoby and Martin Model (Y1lmaz, 2000). The Baumrind (1966), classification for the parental attitude as permissive, 
authoritarian, and authoritative is one of the first studies. However, many studies and classifications have been made regarding the attitudes of parents so far. In this study, only authoritarian, democratic and protective parental attitudes were examined.

Parents who have democratic parental attitude feel sincere, deep and unconditional affection towards child. They are sensitive towards the needs and interests of the child, observe his behavior with interest and tolerance, and permit the child to behave autonomously. They give information about family rules and place specific limits, yet discuss these limits with the child if required (Baumrind, 1966). Since the child can express his feelings and thoughts with ease, he begins to develop confidence (Yavuzer, 2003). Parents who have that sort of attitude respect their child's character by giving unconditional affection and make efforts to develop his sense of responsibility (Gökçedağ, 2001). At the same time, while they give opportunity to child to behave autonomously and utilize them as a source whenever he wants; they explain family rules on the other hand (Baumrind, 1966). Parents who have authoritarian parental attitude form child's behaviors according to social standards and expect him to obey without questioning. They use force and punishment for behaviors apart from these standards (Baumrind, 1966). A child who has grown up in such an environment would feel under pressure and since from an early age the development of self-confidence and self-respect has been restricted (Yavuzer, 2003). Parents who have protective parental attitude are quite cautious and have difficulty in separating from the child. Since they bear the whole responsibility of the child they bring up individuals who are dependent and cannot make their own decisions (Parker, 1983). These children do not confront stressful conditions all through their lives, they therefore experience anxiety when in a stressful environment (Carducci \& Zimbardo, 1995). Those which influence psycho-social development of children are protective attitude which is defined as "overindulgence of children" and authoritarian attitude in which individual rights are not respected (Eldeleklioğlu, 1996). Parental attitudes were studied with variables which influence network of social relations such as problem solving (Hamarta, Baltacı, Üre, \& Demirbaş, 2010), shyness (Demirbaş, 2009) and social anxiety (Erkan, 2002). It is understood that the family environment which is the most suitable for psycho-social development of children and teenagers is the democratic family environment in which there is an equality between parents and children and in which there is a basis of both love and respect (Eldeleklioğlu, 1996).

In the light of the theoretical frame mentioned above it can be suggested that subjective well-being and life satisfaction might be related to given factors. However there has been no study where parental attitude of university students is considered in relation to subjective well-being and life satisfaction. The focus question for this study is: Do parental attitudes significantly predict subjective well-being and life satisfaction?

\section{Method}

\section{Participants}

Sampling of the study consists of 414 students in total, 221 (53\%) females and 193 (47\%) males, who were enrolled at Selcuk University. Age range of the participants is $17-26$, average age is $19.72, \mathrm{SS}=1.54$.

\section{Instruments}

Parental Attitude Scale: The first form of the Parental Attitude Scale was developed by Kuzgun and Eldeleklioğlu (1996). This form was later revised by Kuzgun and Eldeleklioğlu (2005). Perceived parental attitudes are determined by 40 items, Democratic (15 items), Protective (15 items) and authoritarian (10 items). The assessment is a Likert-type Scale each item is scored between 1 and 5. Scores of Democratic, Protective and authoritarian attitudes are measured separately. Coefficient of internal consistency of Democratic sub-scale is .89, stability factor is .92; coefficient of internal consistency of Preventive/Demanding sub-scale is .82 , stability factor is .75 ; coefficient of internal consistency of authoritarian sub-scale is .78, stability factor is .79.

Subjective Well-Being Scale: In the study, data about subjective well-being were obtained using Subjective Well Being Scale developed by Dost (2004). The scale is composed of 46 items and includes personal judgment about living spaces and positive or negative feeling statements. A factor analysis was carried out to assess the validity of SWS; it was determined that SWS has 12 factors whose eigen-value is above 1. Moreover; corrected item-total correlation of the scale was analyzed, and it was observed that it varies between .32 and .63. On the other hand, in order to determine distinctiveness of the test $27 \%$ over under averages of scores which were obtained with the application of 46 item scale on 209 people was compared with t-test.

Cronbach Alpha reliability coefficient of Subjective Well Being Scale was .93. In order to find the consistency coefficient of the scale the scale was applied on 39 people in the study group two times every two weeks and Pearson product moment correlation coefficient was found .86 (Dost, 2004).

Life Satisfaction Scale: The Satisfaction with Life Scale (SWLS) developed by Diener, Emmons, Larsen, and Griffin (1985) and adapted to Turkish by Köker (1991) was used. The SWLS measures global life satisfaction and consists of 5 items of which the values are evaluated according to 7 scores $(1=$ strongly disagree, $7=$ strongly agree). According to the results of the reliability study of the scale, the test retest reliability was $\mathrm{r}=.85$ and item total correlations varied between .71 and .80 .

\section{Procedure}

The data of the study were collected from the students studying at Konya Selcuk University/Turkey. The participants of the study were informed about the aim, measures of the study and the principles of volunteerism. The participants were informed that the papers should be anonymous, but they should be frank in order to facilitate the reliability of the study. The measures were answered approximately in 35 minutes period. Some of the students participated in the study had missing answers on their papers, these students papers were not evaluated.

\section{Analysis of Data}

Data were analyzed with 14.0 SPSS program by using multiple regression analysis and Pearson Correlation Coefficient.

\section{Findings}

Relationship between subjective well being and life satisfaction which are dependent variables and parental attitude which is predictor variable are given in Table $\mathbf{1}$. 
As it is seen in Table 1, there is a positive significant relation between democratic parent attitude and subjective well being ( $\mathrm{r}$ $=.44, \mathrm{r}=42 ; p<.001)$; and negative significant relation between protective parent attitude and subjective well being $(\mathrm{r}=$ $-.26, \mathrm{r}=-.24 ; p<.001)$ and authoritarian parent attitude and subjective well being $(\mathrm{r}=-.40, \mathrm{r}=-.33 p<.01)$.

As it is seen in Table 2; there is a positive significant relation between democratic mother attitude and life satisfaction $(\mathrm{r}=.35$; $p<.001)$, between democratic father attitude and life satisfaction $(\mathrm{r}=.37 ; p<.001)$, negative significant relation between protective mother attitude and life satisfaction $(\mathrm{r}=-.21 ; p$ $<.001$ ), between authoritarian mother attitude and life satisfaction $(\mathrm{r}=-.31 ; p<.001)$; between protective father attitude and life satisfaction $(\mathrm{r}=-.25 ; p<.001)$, between authoritarian father attitude and life satisfaction $(\mathrm{r}=-.26 ; p<.001)$.

Perceived mother attitudes $\left(\mathrm{R}^{2}=.227, \mathrm{~F}=40.235, p<.001\right)$ and perceived father attitudes $\left(\mathrm{R}^{2}=.199, \mathrm{~F}=33.980, p<.001\right)$ of university students predict subjective well-being significantly. Perceived mother attitudes explain $22.7 \%$ pf the variance in subjective well-being, perceived father attitudes explain $19.9 \%$. When the predictors of subjective well being are considered, it was found that democratic and authoritarian mother attitude among perceived mother attitudes; democratic and protective father attitude among father attitudes are significant predictors of life satisfaction.

In Table 4, perceived mother attitudes $\left(\mathrm{R}^{2}=.143, \mathrm{~F}=22.804\right.$,

Table 1.

Correlations between subjective well being and parental attitudes.

\begin{tabular}{lccccc}
\hline & $\begin{array}{c}\text { Democratic } \\
\text { mother }\end{array}$ & $\begin{array}{c}\text { Protective } \\
\text { mother }\end{array}$ & $\begin{array}{c}\text { Authoritarian } \\
\text { mother }\end{array}$ & $\begin{array}{c}\text { Democratic } \\
\text { father }\end{array}$ & $\begin{array}{c}\text { Protective } \\
\text { father }\end{array}$ \\
\hline Sunjective well being & $.44^{* * *}$ & $-.26^{* * *}$ & $-.40^{* * *}$ & $.42^{* * *}$ & $-.24^{* * *}$ \\
\hline
\end{tabular}

Note: ${ }^{* * *} p<.001$.

Table 2.

Correlations between life satisfaction and parental attitudes.

\begin{tabular}{cccccc}
\hline & $\begin{array}{c}\text { Democratic } \\
\text { mother }\end{array}$ & $\begin{array}{c}\text { Protective } \\
\text { mother }\end{array}$ & $\begin{array}{c}\text { Authoritarian } \\
\text { mother }\end{array}$ & $\begin{array}{c}\text { Democratic } \\
\text { father }\end{array}$ & $\begin{array}{c}\text { Protective } \\
\text { father }\end{array}$ \\
\hline Life satisfaction & $.35^{* * *}$ & $-.21^{* * *}$ & $-.31^{* * *}$ & $.37^{* * *}$ & $-.25^{* * *}$ \\
\hline
\end{tabular}

Note: ${ }^{* * *} p<.001$.

Table 3.

Explanation of well being by parental attitudes.

\begin{tabular}{|c|c|c|c|c|c|}
\hline Dependent variable & $\mathbf{R}^{2}$ & $\mathbf{F}$ & $\boldsymbol{\beta}$ & Independent variables & $t$ \\
\hline \multirow{2}{*}{ Well being } & \multirow{2}{*}{.227} & \multirow{2}{*}{$40.235^{* * *}$} & .310 & Democratic mother & $5.823^{* * *}$ \\
\hline & & & -.201 & Authoritarian mother & $-3.139^{* *}$ \\
\hline \multirow{3}{*}{ Well being } & \multirow{3}{*}{.199} & \multirow{3}{*}{$33.980^{* * *}$} & .348 & Democratic father & $6.591^{* * *}$ \\
\hline & & & -.109 & Protective father & $-2.037^{*}$ \\
\hline & & & -.079 & Authoritarian father & -1.284 \\
\hline
\end{tabular}

Note: ${ }^{*} p<.05,{ }^{* *} p<.01,{ }^{* * *} p<.001$.

Table 4.

Explanation of life satisfaction by parental attitudes.

\begin{tabular}{|c|c|c|c|c|c|}
\hline Dependent variable & $\mathbf{R}^{2}$ & $\mathbf{F}$ & $\beta$ & Independent variables & $t$ \\
\hline \multirow{3}{*}{ Life satisfaction } & \multirow{3}{*}{.143} & \multirow{3}{*}{$22.804^{* * *}$} & .267 & Democratic mother & $4.761^{* * *}$ \\
\hline & & & -.058 & Protective mother & -1.009 \\
\hline & & & -.118 & Authoritarian mother & -1.755 \\
\hline \multirow{3}{*}{ Life satisfaction } & \multirow{3}{*}{.158} & \multirow{3}{*}{$25.641^{* * *}$} & .328 & Democratic father & $6.045^{* * *}$ \\
\hline & & & -.169 & Protective father & $-3.084^{* *}$ \\
\hline & & & .013 & Authoritarian father & .206 \\
\hline
\end{tabular}

Note: ${ }^{* *} p<.01,{ }^{* * *} p<.001$. 
$p<.001)$ and perceived father attitudes $\left(\mathrm{R}^{2}=.158, \mathrm{~F}=25.641, p\right.$ $<.001)$ explain life satisfaction significantly. Perceived mother attitudes explain $14.3 \%$ of the variance in life satisfaction, perceived father attitudes explain $15.8 \%$ of the variance in life satisfaction. When the predictors of life satisfaction are considered, it was found that only democratic mother attitude among perceived mother attitudes; and democratic and protective father attitude among father attitudes are significant predictors of life satisfaction.

\section{Discussion and Recommendations}

According to the findings obtained in this study, there are significant relations between parental attitudes, subjective well being and life satisfaction. Findings show that parental attitudes are important variables which predict subjective well being and life satisfaction. This finding has similarity with the findings of Tuzgöl Dost (2006, 2010), Petito and Cummins (2000), Sastre and Ferriere (2000) and Shek (2005). In this study the subjective well-being of university students who perceive their parent as democratic was higher than those students who perceive their parents as authoritarian and preventive. Children who are brought up in a democratic environment being loved unconditionally, presenting their emotion and thoughts freely, participating in the decisions about himself, being given responsibility and permission to behave autonomously may enable them to develop self-confidence (Baumrind, 1966; Gökçedağ, 2001; Yavuzer, 2003) and this might increase their subjective well-being.

The findings of this study show that there is a positive relation between democratic parental attitude and subjective well being and life satisfaction, and a negative relationship between protective and authoritarian parental attitude and subjective well being and life satisfaction. According to research, while positive perception of family functions is related with high psychological well being, social support from family is a significant predictor of life satisfaction (Suldo \& Huebner, 2004). This finding has great contribution in explanation of high subjective well being of individuals who are brought up in a democratic family environment. Moreover active participation of individuals in the decisions about themselves helps to enable important life satisfaction in the sense of developing sense of responsibility and controlling changes in his life.

The negative relation between protective father attitude and subjective well being and life satisfaction indicates that while university students wish their parent to support them without interfering less, it points to the necessity that prevention shall not be related with interference. Findings show that perceived parental attitudes are important factors in subjective well being of individuals and attaining life satisfaction. Life satisfaction, warm family environment are influenced by democratic attitude towards children and family support (Saha, Huebner, Suldo, \& Valois, 2010; Young, Miller, Norton, \& Hill, 1995; Leung \& Leung, 1992; Shek, 1997a; BrajšaŽganec, Šakić, \& RabotegŠarić, 2004).

The similarity between American (Dew \& Huebner's, 1994) and Chinese (Leung \& Leung, 1992; Shek, 1997) sampling and Turkish sampling as a result of this study makes us to think that supporting the independence of teenagers in societies during development process would contribute to their subjective well being, development of life satisfaction and social participation significantly. Thus, researches carried out on the fact that teen- agers who are brought up in a supportive family environment communicate more actively and feel more comfortable in communicating (Joronen \& Åstedt-Kurki, 2005) are supporting the findings of the study.

In addition among the other perceived parental attitudes, it is seen that there are important relations between perceived democratic parental attitude and life satisfaction and subjective well being. When we consider that individuals having internal locus of control and autonomous are coming from democratic families (Baumrind, 1971) education, seminars and informative studies which will enable parents to form democratic attitudes towards their children may have important contributions. The main restriction of the study was that it was only carried out on university students. In this sense, in order to increase generalization of the study; groups including childhood and adolescence periods and parent sampling may have important contribution to the study field.

\section{REFERENCES}

Aksaray, S., Yıldız, A., \& Ergün, A. (1998). Huzurevi ve evde yaşayan yaşlıların umutsuzluk düzeyleri. Ulusal Evde Bakım Kongresi, Program Özet Kitabı.

Antaramian, S. P., Huebner, E. S., \& Valois, R. F. (2008). Adolescent life satisfaction. Applied Psychology: An International Review, 57, 112-126. doi:10.1111/j.1464-0597.2008.00357.x

Baumrind, D. (1966). Effects of authoritarian parental control on child behaviors. Child Development, 37, 887-907. doi:10.2307/1126611

Baumrind, D. (1971). Current patterns of parental authority. Developmental Psychology Monographs, 4, 1-103. doi:10.1037/h0030372

Baumrind, D. (1980). New directions in socialization research. American Psychologist, 35, 639-652. doi:10.1037/0003-066X.35.7.639

Bradley, R. H., \& Corwyn, R. F. (2004). Life satisfaction among european american, african american, chinese american, mexican american and dominican american adolescents. International Journal of Behaviour Development, 28, 385-400. doi:10.1080/01650250444000072

BrajšaŽganec, A., Šakić, M., \& RabotegŠarić, Z. (2004). Life satisfaction in adolescents: The effects of perceived family economic status, selfesteem and quality of family and peer realtionships. Social Research Journal for General Social Issues, 3, 547-564.

Carducci, J. B., \& Zimbardo, G. F. (1995). Are you shy? Psychology Today, 28, 34-46.

Demirbaş, E. (2009). Examination of shyness and self-esteem of high school students from the point of view of dysfunctional attitude. Unpublished Master Thesis, Konya: Selcuk University, Social Sciences Institude.

Dew, T., \& Huebner, E. S. (1994). Adolescents' perceived quality of life: An exploratory investigation. Journal of School Psychology, 33, 185-199. doi:10.1016/0022-4405(94)90010-8

Deniz, M. E., \& Yilmaz, E. (2004). The relationship between the emotional intelligence abilities and life satisfaction of the university students. 8th National Education Sciences Congress, 6-9 February 2004, Malatya: Inonu University, Faculty of Education.

Deniz, M. E. (2006). The relationships among coping with stress, life satisfaction, decision making styles and decision self-esteem: an investigation on turkish university students. Social Behavior and Personality: An International Journal, 34, 1161-1170. doi:10.2224/sbp.2006.34.9.1161

Dew, T., \& Huebner, E. S. (1994). Adolescents' perceived quality of life: An exploratory investigation. Journal of School Psychology, 33, 185-199. doi:10.1016/0022-4405(94)90010-8

Diener, E. (1984). Subjective well-being. Psychological Bulletin, 95(3), 542-575. doi:10.1037/0033-2909.95.3.542

Diener, E, Emmons, R. A., Larsen, R. J., \& Griffin, S. (1985). The satisfaction with Life Scale. Journal of Personality Assessment, 49, 71-75. doi: $10.1207 / \mathrm{s} 15327752 \mathrm{jpa} 4901 \_13$ 
Diener, E. (2000). Subjective well-being: The science of happiness and a proposal for a national index, American Psychology, 55, 34-43. doi:10.1037/0003-066X.55.1.34

Diener, E., Suh, E. M., \& Lucas, R. E. (2003). Personality, culture and subjective well-being: Emotional and cognitive evaluation of life. Annual Review of Psychology, 54, 403-428. doi:10.1146/annurev.psych.54.101601.145056

Dost, M. (2004). The subjective well-being levels of the university students. Unpublished Doctoral Dissertation, Ankara: Hacettepe University, Social Sciences Institute.

Eldeleklioğlu, J. (1996). The relation between decision strategies and parental attitudes. Unpublished Doctoral Dissertation, Ankara: Gazi University, Social Sciences Institute.

Erkan, Z. (2002). A study on the social anxiety levels, parental attitudes of adolescence and the risk factors seen within the family. Unpublished Doctoral Dissertation, Ankara: Cukurova University Educational Sciences Institute.

Furnham, A., \& Cheng, H. (2000). Perceived parental behavior, self esteem and happiness. Social Psychiatry Epidemiology, 35, 463-470. doi:10.1007/s001270050265

Gökçedağ, S. (2001). The determination and comparison of the effect of parental attitudes on high school students' academic achievement and anxiety levels. Unpublished Master Thesis, Izmir: Dokuz Eylul University, Social Sciences Institude.

Hamarta, E. (2009). A prediction of self-esteem and life satisfaction by social problem solving. Social Behavior and Personality, 37, 73-82. doi: $10.2224 / \mathrm{sbp} .2009 .37 .1 .73$

Hamarta, E., Baltacı, Ö., Üre, Ö., \& Demirbaş, E. (2010). Lise öğrencilerinin utangaçlıklarının algılanan anne baba tutumları ve problem çözme yaklaşımları açısından incelenmesi. Aile ve Toplum Dergisi, 21, 73-82.

Huebner, E. S., Gilman, R., \& Laughlin, J. E. (1999). A multimethod investigation of the multidimensionality of children's well-being reports: Discriminant validity of life satisfaction and self-esteem. Social Indicators Research, 46, 1-22. doi:10.1023/A:1006821510832

Joronen K., \& Åstedt-Kurki, P. (2005). Familial contribution to adolescent subjective well-being, International Journal of Nursing Practice, 11, 125-133. doi:10.1111/j.1440-172X.2005.00509.x

Köker, S. (1991). The comparison of the life satisfaction level of psychologically healthy and unhealthy adolescence. Unpublished Master Thesis, Ankara: Ankara University, Social Sciences Institude.

Kuzgun, Y., \& Eldeleklioğlu, J. (2005). Rehberlik ve psikolojik danışmada kullanılan ölçme araçları ve programlar dizisi. Ankara: Nobel Yayın Dağıtım.

Leung, J. P., \& Leung, K. (1992). Life satisfaction, self-concept, and relationship with parents in adolescence. Journal of Youth and Adolescence, 21, 653-665. doi:10.1007/BF01538737

Myers, D., \& Diener, E. (1995). Who is happy. American Psychological Society, 6, 1-19.

Parker, G. (1983). Parental over protection: A risk factor in psychocial development. New York: Grune and Stratton Inc.

Petito, F., \& Cummins, R. A. (2000). Quality of life in adolescence: The role of perceived control, parenting style and social support. Behaviour Change, 17, 196-207. doi:10.1375/bech.17.3.196

Ryan, R. M., \& Deci, E. L. (2001). On happiness and huma potatials: A reviow of research on hedonic and eudemonic well-being. Annual Review Psychology, 52, 141-166. doi:10.1146/annurev.psych.52.1.141

Ryff, C. D., \& Keyes, C. L. M. (1995). The structure of psychological well-being revisited. Journal of Personality and Social Psychology,
69, 719-727. doi:10.1037/0022-3514.69.4.719

Saha, R., Huebner, S. E., Suldo, S. M., \& Valois, R. F. (2010). A longitudinal study of adolescent life satisfaction and parenting. Child Indicators Research, 3,149-165. doi:10.1007/s12187-009-9050-x

Sastre, M. T. M., \& Ferriere, G. (2000). Family decline and the subjective wellbeing of adolescent. Social Indicators Research, 49, 69-82. doi:10.1023/A:1006935129243

Shek, D. T. L. (1997). The relation of family functioning to adolescent psychological well-being, school adjustment, and problem behavior. The Journal of Genetic Psychology, 158, 467-479. doi:10.1080/00221329709596683

Shek, D. T. L. (2005). A longitudinal study of perceived family functioning and adolescent adjustment in chinese adolescents with economic disadvantage. Journal of Family Issues, 26, 518-543. doi:10.1177/0192513X04272618

Suldo, S. M., \& Huebner, E. S. (2004). The role of life satisfaction in the relationship between authoritarian parenting dimensions and adolescent problem behavior. Social Indicators Research, 66, $165-$ 195. doi:10.1023/B:SOCI.0000007498.62080.1e

Tümkaya, S., Hamarta, E., Deniz, M. E., Çelik, M., \& Aybek, B. (2008). Duygusal zeka mizah tarzı ve yaşam doyumu: Üniversite öğretim elemanları üzerine bir araştırma, Türk Psikolojik Danışma ve Rehberlik Dergisi, 3, 1-18.

Tuzgöl, M. (2000). Ana-baba tutumları farklı lise öğrencilerinin saldırganlık düzeylerinin çeşitli değișkenler açısından incelenmesi. Türk Psikolojik Danışma ve Rehberlik Dergisi, 2, 39-48.

Tuzgöl Dost, M. (2006). Subjectıve well-being among university students. Hacettepe Üniversitesi Eğitim Fakültesi Dergisi, 31, 188197.

Tuzgöl Dost, M. (2010). Güney Afrika ve Türkiye'deki üniversite öğrencilerinin bazı değişkenlere göre öznel iyi oluş ve yaşam doyumlarının incelenmesi. Eğitim ve Bilim, 35, 75-89.

Toros, T. (2001). The effect of goal orientation motivational climate and the goal's authenticity and difficulty level on life satisfaction among elite and non elite male basketball players. Unpublished Master Thesis, Mersin: Mersin University, Faculty of Health Sciences.

Vara, S. (1999). A study on the factors affecting the job satisfaction and the life satisfaction of the nurses working at intensive care services. Unpublished Master Thesis, Izmir: Ege University, Faculty of Health Sciences.

Veenhoven, R. (1996). The study of life satisfaction. In W. E. Saris, R. Veenhoven, A. C. Scherpenzeel, \& B. Bunting (Eds.), A comparative study of satisfaction with life in Europe (pp. 11-48). Budapest: Eötvös University Press.

Yavuzer, H. (2003). Çocuğu tanımak ve anlamak. İstanbul: Remzi Kitabevi.

Yetim, U. (1991). Kişisel projelerin organizasyonu ve örüntüsü açısından yaşam doyumu. Yayınlanmamış doktora tezi. İzmir: Ege Üniversitesi, Sosyal Bilimler Enstitüsü.

Yılmaz, A. (2000). Eşler arasındaki uyum ve çocuğun alglladı̆̆ anne-baba tutumu Ille çocukların, ergenlerin, gençlerin akademik başarıları ve benlik algıları arasındaki ilişkiler. Yayınlanmamış Doktora Tezi. Ankara: Hacettepe Üniversitesi Sosyal Bilimler Enstitüsü.

Young, M. H., Miller, B. C., Norton, M. C., \& Hill, E. J. (1995). The effect of parental supportive behaviors on life satisfaction of adolescent offspring. Journal of Marriage and Family, 57, 813-822. doi: $10.2307 / 353934$ 